\title{
Pemberdayaan Masyarakat Nagari Sijunjung Melalui Pemanfaatan Rumah Gadang Sebagai Tempat Penginapan Wisatawan Geopark Silokek
}

\author{
Abdul Rauf ${ }^{1}$, Fitri Eriyanti ${ }^{2}$ \\ 1,2Universitas Negeri Padang \\ Email: abdulraufmalinkayo@gmail.com, fitri.eriyanti@fis.unp.ac.id
}

\begin{abstract}
Abstrak
Pemanfaatan Rumah Gadang sebagai tempat penginapan bagi wisatawan terbilang masih baru. Oleh karena itu kesamaan persepsi dan pemahaman, sosialiasi serta pelatihan kepada masyarakat belum terlaksana secara efektif. Tujuan penelitian untuk memberdayakan masyarakat, menjelaskan kendala dan memberikan solusi atas kendala. Metode yang digunakan ialah kualitatif dengan menggunakan pendekatan deskriptif. Keberadaan Rumah Gadang di Nagari Sijunjung dapat dimanfaatkan untuk memberdayakan masyarakat Nagari Sijunjung. Upaya pemberdayaan masyarakat dengan memaksimalkan potensi kearifan lokal yang dimiliki yakni Rumah Gadang Perkampungan Adat dengan dibantu dan dampingi oleh pemerintah telah dapat menjadi sumber pemasukan secara ekonomi bagi masyarakat yang menghuni Rumah Gadang. Kendala yang masih ditemukan ialah manajemen pengelolaan yang masih belum baik dan fasilitas yang belum maksimal sehingga perlu dilakukan percepatan untuk perbaikan.
\end{abstract}

Kata Kunci: Pemberdayaan Masyarakat, Rumah Gadang, penginapan wisatawan

\section{Abstract}

The use of the Rumah Gadang as a place of lodging for tourists is still fairly new. Therefore the common perception and understanding, socialization and training to the community have not been implemented effectively. The purpose of the research is to empower the community, explain constraints and provide solutions to constraints. The method used is qualitative using a descriptive approach. The existence of the Rumah Gadang in Nagari Sijunjung can be used to empower the people of Nagari Sijunjung. The effort to empower the community by maximizing the potential of local wisdom that is owned by the Rumah Gadang Perkampungan Adat by being assisted and accompanied by the government has become a source of economic income for the people who inhabit the Gadang House. Constraints that are still found are management management that is still not good and facilities that have not been maximized so that it needs to be accelerated for repairs.

Keywords: Community Empowerment, Rumah Gadang, tourist accommodation

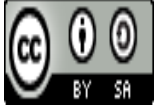

Received: July 26, $2019 \quad$ Revised: July 30, $2019 \quad$ Available Online: July 31, 2019 


\section{Pendahuluan}

Komite Nasional Geopark Indonesia, menetapkan Silokek sebagai Geopark Nasional. Status sebagai Geopark Nasional ditetapkan pada Jum'at (30/11/2018) yang ditandai dengan penyerahan sertifikat Geopark Nasional oleh Menteri Pariwisata, Arief Yahya kepada Bupati Sijunjung, Yuswir Arifin di Museum Tambang Antam Jawa Barat. Geopark Silokek merupakan kawasan Taman Bumi yang berada di Kabupaten Sijunjung dengan sebaran spot/geosite pada dua kecamatan yakni Kecamatan Sumpur Kudus dan Kecamatan Sijunjung.

Adanya Geopark Silokek membawa banyak keuntungan bagi kehidupan masyarakat di Sijunjung yakni pembangunan ekonomi. Sesuai dengan satu pilar utama dalam program geopark ialah pembangunan perekonomian masyarakat secara berkelanjutan melalui pengembangan sektor pariwisata. Setiap geosite ini mempunyai ciri khas, keunikan, dan punya daya tarik tersendiri yang pada akhirnya melahirkan nilai kepariwisataan. Sehingga nilai kepariwisataan mampu menumbuhkan dan meningkatkan sektor-sektor perekonomian masyarakat setempat.

Salah satu geosite yang ada pada Geopark Silokek ialah Perkampungan Adat yang ada di Nagari Sijunjung berupa deretan rumah adat Minangkabau yakni Rumah Gadang yang berjumlah kurang lebih 85 (delapan puluh lima) bangunan. Keberadaan bangunan Rumah Gadang ini masih terjaga nilai keaslian bentuk dan fungsinya. Rumah Gadang masih dikelola dan dihuni oleh masyarakat setempat sebagai rumah hunian sebagaimana rumah masyarakat umumnya.

Pemerintah Kabupaten Sijunjung bersama-sama dengan unsur masyarakat Nagari Sijunjung menjadikan Perkampungan Adat tersebut sebagai tempat penginapan (homestay) bagi para wisatawan yang mengunjungi Geopark Silokek. Hal ini menjadi destinasi wisata sehingga masyarakat menjadi berdaya secara ekonomi dengan adanya pembayaran atau biaya yang dibayarkan oleh wisatawan yang menginap di Rumah Gadang tersebut.

Data awal yang didapatkan tentang pemanfaatan Rumah Gadang sebagai tempat penginapan wisatawan ini ialah; pernyataan Sekretaris Nagari Kenagarian Sijunjung yang membenarkan bahwa Rumah Gadang memang dijadikan sebagai penginapan (homestay). Rumah Gadang yang dijadikan sebagai tempat penginapan tersebut berjumlah sebanyak 16 (enam belas) bangunan rumah gadang. Rumah Gadang tersebut dikelola sebagai penginapan oleh masyarakat yang menghuni Rumah Gadang itu sendiri.

Menjadikan Rumah Gadang sebagai tempat penginapan bagi wisatawan Geopark masih sangat baru yakni dari awal tahun 2018. Oleh karena itu sosialisasi serta pelatihan kepada masyarakat oleh pemerintah belum terlaksana secara efektif. Sehingga masyarakat belum punya pemahaman yang sama tentang konsep pelayanan kepariwisataan. Hal ini tentu menjadi suatu hambatan serta kendala bagi pihak pemerintah untuk untuk pengembangan Geopark. Selanjutnya yang menjadi hambatan ialah menyamakan persepsi masyarakat dengan harapan dan tujuan pemerintah dalam memperbaiki kehidupan mereka.

Peran Pemerintah Kabupaten Sijunjung dalam pengelolaan Rumah Gadang sebagai tempat penginapan wisatawan ialah fasilitator, legalisator dan promotor bagi masyarakat Nagari Sijunjung. Dalam pelaksanaan di lapangan secara teknis dilakukan oleh masyarakat setempat. Hal ini menjadi kendala antara masyarakat dengan pemerintah dalam hal standar penetapan tarif yang dikenakan kepada wisatawan. Masyarakat tidak ingin diintervensi dalam hal penetapan biaya, sehingga hal ini menjadi salah satu hambatan pemerintah dalam mengembangkan Perkampungan Adat sebagai tempat penginapan bagi wisatawan Geopark Silokek.

Kondisi pekarangan Rumah Gadang yang dijadikan sebagai tempat penginapan ialah pekarangan Rumah Gadang tersebut belum tertata dengan baik dan rapi. Mulai dari pagar 
pekarangan yang belum rapi dan seragam, rumput liar masih banyak di pekarangan, antena televisi (parabola) masih ada di halaman depan rumah sehingga pekarangan tertutup. Selanjutnya dari segi fasilitas penunjang seperti kamar mandi belum ada pada semua Rumah Gadang serta ruang untuk tempat ibadah belum tertata. Kemudian, Masyarakat belum bisa menampilkan sikap keramah-tamahan sebagaimana perilaku masyarakat Minangkabau sesungguhnya (baik dalam bertutur kata, dan berpakaian) yang akan membuat wisatawan nyaman untuk mengunjungi dan menginap di Perkampungan Adat tersebut.

Untuk itu, masyarakat diharapkan punya kemapuan dan kapasitas dalam pengelolaan tempat Penginapan dan layanan kapariwisataan. Sehingga, dengan dijadikannya Rumah Gadang sebagai tempat penginapan (homestay) bagi wisatawan dapat memberikan dampak finansial yakni menumbuhkan perekonomian masyarakat setempat yang kemudian kehidupan masyarakat menjadi sejahtera. Oleh karena itu, perlu adanya kerjasama yang baik antara pemerintah Kabupaten Sijunjung dengan unsur masyarakat Nagari Sijunjung agar harapan tersebut dapat berjalan dan tercapai dengan baik. Serta hambatan-hambatan maupun kendala yang ada dapat diselesaikan sehingga mendapatkan solusi yang konstruktif untuk perbaikan dan kemajuan kehidupan masyarakat Nagari Sijunjung melalui pemanfaatan Rumah Gadang tersebut.

Berdasarkan kondisi tersebut maka dirumuskan permasalahan sebagai berikut: 1)Bagaimana pemberdayaan masyarakat Nagari Sijunjung melalui pemanfaatan Rumah Gadang sebagai tempat penginapan bagi wisatawan Geopark Silokek; 2)Apa kendala pemberdayaan masyarakat Nagari Sijunjung melalui pemanfaatan Rumah gadang sebagai tempat penginapan bagi wisatawan Geopark Silokek; 3)Apa solusi untuk mengatasi kendala pemberdayaan masyarakat Nagari Sijunjung melalui pemanfaatan Rumah gadang sebagai tempat penginapan bagi wisatawan Geopark Silokek. Sehingga dapat menjawab penelitian yang berjudul "pemberdayaan masyarakat Nagari Sijunjung melalui pemanfaatan Rumah Gadang sebagai tempat penginapan wisatawan Geopark Silokek”

Penelitian ini dilakukan bertujuan Untuk memberdayakan masyarakat Nagari Sijunjung melalui pemanfaatan Rumah Gadang sebagai tempat penginapan bagi wisatawan Geopark Silokek. Kemudian untuk menjelaskan kendala dalam pemberdayaan masyarakat Nagari Sijunjung melalui pemanfaatan Rumah Gadang sebagai tempat penginapan. Serta untuk memberikan solusi atas kendala dalam pemberdayaan masyarakat Nagari Sijunjung melalui pemanfaatan Rumah gadang sebagai tempat penginapan bagi wisatawan Geopark Silokek.

Selanjutnya, pemberdayaan masyarakat menurut Rappaport dalam Totok Mardikanto dan Poerwoko (2015 : 29) ialah suatu cara agar rakyat, komunitas, dan organisasi diarahkan agar mampu menguasai atau berkuasa atas kehidupannya.pemberdayaan masyarakat merupakan suatu proses dalam upaya memperkuat "Community self Reliance" atau kemandirian komunitas. Pada proses pemberdayaan tersebut, masyarakat didampingi baik saat menganalisis masalah yang dihadapi maupun dibantu agar menemukan alternatif solusi masalah tersebut. Kemudian akan diperlihatkan beragam pendekatan atau strategi menggunakan berbagai sumber daya yang dimiliki dan dikuasai. Artinya, dalam upaya memberdayakan masyarakat ada pihak yang memberikan ransangan atau kekuatan (empowerment) untuk mencapai maksud tersebut. Masyarakat perlu ada pendekatan dan pendampingan sampai mereka berada pada keadaan mandiri atau berdaya.

Pemberdayaan Masyarakat memiliki prinsip-prinsip menurut Dahama dan Bahtanar dalam Mardikanto (2015: 106-108) yang mencangkup sebagai berikut; 1) minat dan kebutuhan; 2) Organisasi masyarakat bawah; 3) Keragaman budaya; 4)Perubahan budaya; 5) Kerjasama dan partisipasi; 6) Demokrasi dalam penerapan ilmu; 7) Belajar sambil bekerja; 8) Penggunaan metoda yang sesuai; 9) Kepemimpinan; 10) Spesialis yang terlatih; 11)Segenap keluarga dan; 12) Kepuasan. 
Pemberdayaan masyarakat melingkupi beberapa hal yakni menurut Totok Mardikanto (2013: 114-117) ; 1)Bina manusia, pemahaman ini menekankan bahwa tujuan pembangunan ialah untuk perbaikan mutu hidup atau kesejahteraan manusia.Upaya yang dilakukan ialah pengembangan kapasitas individu, Pengembangan kapasitas entitas/kelembagaan, Pengembangan kapasitas sistem (jejaring); 2)Bina Usaha yang meliputi memilih komoditas dan jenis usaha, studi kelayakan dan perencanaan bisnis, membentuk badan usaha, merencanakan investasi dan sumber biaya, manajerial produksi dan operasi, manajerial logistik dan finansial, penelitian dan pengembangan, mengembangkan sistem informasi, mengembangkan jejaring dan kemitraan, serta sarana dan prasarana pendukung; 3)Bina Lingkungan, untuk menjaga keberlansungan pembangunan agar tetap berkelanjutan maka perlu pelestarian lingkungan (baik fisik atau sosial) agar keberlansungan kegiatan investasi maupun operasi dapat terlindungidan; 4)Bina kelembagaan, merupakan penentu keberhasilan dari bina manusia, bina usaha dan bina lingkungan oleh tersedia dan efektifnya bina kelembagaan. Teori yang digunakan dalam penelitian pemberdayaan masyarakat ini mengacu pada teori ACTORS tentang pemberdayaan yang dikemukakan oleh Sarah Cook dan Steve Macaulay dalam Karjuni (2011:59-63) yang memandang masyarakat sebagai subyek yang dapat melakukan perubahan dengan cara membebaskan seseorang dari kendali yang kaku dan memberi orang tersebut kebebasan untuk bertanggungjawab terhadap ide-ide, keputusankeputusannya, dan tindakan-tindakannya. Kerangka kerja pemberdayaan dapat dilihat dari akronim "ACTORS" antara lain terdiri dari:

$\mathrm{A}=$ authority (wewenang) dengan memberikan kepercayaan

$\mathrm{C}=$ confidence and competence (rasa percaya diri dan kemampuan)

$\mathrm{T}=$ trust (keyakinan)

$\mathrm{O}=$ oppurtinities (kesempatan)

$\mathrm{R}=$ responsibilities (tanggungjawab)

$\mathrm{S}=$ support (dukungan)

Dengan menggunakan teori yang ditawarkan Cook dan Macaulay ini, maka perubahan yang akan dihasilkan merupakan suatu perubahan yang bersifat terencana karena input yang akan digunakan dalam perubahan telah diantisipasi sejak dini sehingga output yang akan dihasilkan mampu berdayaguna secara optimum.

Pemanfaatan Rumah Gadang sebagai tempat penginapan bagi wisatawan relevan dengan konsep ekowisata. Karena Rumah Gadang yang ada di Nagari Sijunjung ini merupakan bagian dari geosite Geopark Silokek, maka prinsipnya berbeda dari destinasi wisata konvensional karena kegiatanya menaruhkan perhatian besar pada kelestarian sumberdaya pariwisata. Sebagaimana Menurut Fandeli dalam Yulia (2017:5) yang mengatakan ekowisata merupakan kegiatan wisata yang memanfaatkan jasa lingkungan. Baik itu alam maupun masyarakat dengan mengemukakan unsur-unsur koservasi, edukasi dan pemberdayaan masyarakat setempat.

\section{Metode Penelitian}

Penelitian ini merupakan penelitian kualitatif dengan menggunakan tipe deskriptif, untuk mengeksplorasi dan mamahami makna dari masalah sosial dan kemanusiaan. Penelitian ini dilakukan di Nagari Sijunjung tepatnya pada Jorong Tanah Bato dan Jorong Padang Ranah yang merupakan daerah tempat berdirinya bangunan-bangunan Rumah Gadang. Teknik yang digunakan untuk menentukan informan ialah dengan purposive sampling, yaitu pemilihan sumber data dari orang yang diwawancarai dengan pertimbangan dan tujuan tertentu (Kepala Dinas Pariwisata Pemuda dan Olahraga Kabupaten Sijunjung, Walinagari Sijunjung, Pemangku Kepentingan Nagari Sijunjung, pengelola homestay,tokoh masyarakat dan wisatawan. 
Teknik pengumpulan data menggunakan metode wawancara dengan alat pedoman wawancara, Observasi dan dokumentasi. Untuk menguji keabsahan data peneliti menggunakan teknik trianggulasi sumber dan teknik karena data yang diperoleh merupakan data dari banyak sumber, yakni membandingkan dan mencek balik derajat kepercayaan atau informasi yang diperoleh melalui orang-orang (sumber) yang berbeda. Teknik Analisis Data dilakukan dengan tiga tahap yakni tahap reduksi Data, tahap penyajian data, dan tahap penarikan kesimpulan verifikasi.

\section{Hasil dan Pembahasan}

\section{Hasil Penelitian}

Berdasarkan penelitian yang telah dilakukan maka dapat ditemukan beberapa hasil sebagai berikut ini: 1) Pemberdayaan masyarakat Nagari Sijunjung dalam pemanfaatan Rumah Gadang sebagai tempat penginapan bagi wisatawan telah dapat meningkatkan dan menambah perekonomian masyarakat Nagari Sijunjung. Dalam pemberdayaan tersebut masyarakat dibina, diberi pehaman dan pelatihan dan support serta banyak pihak yang bertanggungjawab terhadap hal tersebut sehingga masyarakat semakin berdaya dan punya power untuk merubah keadaan hidup mereka. Pihak-pihak juga banyak yang berkontribusi dan mensuport kegiatan tersebut mulai dari Pemerintah Daerah Kabupaten Sijunjung, Pemerintah Nagari Sijunjung, Pemangkupemangku kepentingan yang ada di Nagari Sijunjung serta badan-badan usaha; 2) Kendala yang ditemui dalam pemberdayaan masyarakat Nagari Sijunjung dalam pemanfaatan Rumah Gadang sebagai tempat penginapan ialah tata kelola adaministrasi oleh pihak pengelola homestay belum berjalan dengan baik, Masih adanya kelemahan pada fasilitas Rumah Gadang yang dirasakan oleh wisatawan, Belum ada kios pusat oleh-oleh untuk menjual souvenir, atau produk-produk khas Nagari Sijunjung di Perkampungan Adat; 3)Solusi yang diupayakan oleh Dinas PARPORA dan Pemerintah Nagari Sijunjung untuk mengatasi kendala yakni terus melakukan pembenahan ke arah yang lebih baik dengan menganggarkan pembangunan fasilitas-fasilitas di Perkampungan Adat, Pemerintah Nagari Sijunjung telah membuat peraturan nagari tentang perkampungan adat yang didalamnya termuat semua aturan main pada perkampungan adat dan tempat penginapan.

\section{Pembahasan}

Keberadaan Rumah Gadang di Nagari Sijunjung dapat dimanfaatkan untuk memberdayakan masyarakat Nagari Sijunjung. Hal tersebut dapat diketahui dengan telah dijadikannya Rumah Gadang yang ada di Perkampungan Adat sebagai tempat penginapan/homestay bagi wisatawan yang berkunjung ke Sijunjung. Rumah Gadang tersebut selain difungsikan sebagai tempat tinggal bagi masyarakat juga dimanfaatkan sebagai tempat penginapan yang punya nilai ekonomis dan menjadi pemasukan bagi masyarakat. Kegiatan pemberdayaan ini dilakukan berdasarkan potensi yang dimiliki oleh Nagari Sijunjung yakni Perkampungan Adat yang mempunyai keunikan serta nilai kebudayaan yang tinggi.

Pemberdayaan masyarakat melalui pemanfaatan Rumah Gadang sebagai tempat penginapan juga sejalan dengan hasil penelitian Joko Sutarto dan kawan-kawan tentang "Model Pemberdayaan Masyarakat Melalui Pelatihan Kecakapan Hidup Berbasis Keunggulan Lokal Desa Wisata Mandiri Wanurejo Borobudur Magelang” mengatakan bahwa potensi alam dan budaya yang ada di desa Wanurejo memberikan dampak positif bagi peningkatan kesejahteraan ekonomi masyarakat. Banyaknya wisatawan yang berkunjung membuka peluang baru bagi kegiatan perekonomian masyarakat yang tadinya hanya mengandalkan sektor pertanian sekarang merambah ke sektor kerajinan. Hal tersebut 
menunjukan bahwa kegiatan pemberdayaan masyarakat melalui pelatihan kecakapan hidup dianggap telah mampu mengangkat potensi lokal ke kancah nasional dengan model pengelolaan khusus yang disesuaikan dengan kebutuhan dan kondisi lingkungan sekitar.

Pemberdayaan masyarakat Nagari Sijunjung melalui pemanfaatan Rumah Gadang sebagai tempat penginapan merupakan upaya pemberdayaan dengan cara memperkuat kemandirian masyarakat dengan memaksimalkan potensi kearifan lokal yang mereka miliki yakni Rumah Gadang yang ada di Perkampungan Adat. Masyarakat Nagari Sijunjung dibantu dan didampingi oleh pemerintah untuk menambah nilai ekonomi dari Rumah Gadang tersebut dengan mengarahkan ke sektor pariwisata. Sehingga hal ini telah dapat menjadi sumber pemasukan secara ekonomi bagi masyarakat Nagari Sijunjung yang menghuni Rumah Gadang. Kegiatan ini sejalan dengan hasil penelitian yang dilakukan oleh Furqan tentang "Pemberdayaan Masyarakat Melalui Tradisi Mawah (Studi Kasus Pemeliharaan ternak Sapi Di Desa Mibo Kecamatan Banda Raya Banda Aceh)" yang mengatakan bahwa Pemberdayaan merupakan upaya untuk mendorong, memotivasi, dan membangkitkan kesadaran masyarakat akan potensi yang dimiliki dan berupaya untuk mengembangkan potensi itu. Pemberdayaan masyarakat adalah upaya untuk membantu masyarakat yang kurang mampu menjadi masyarakat yang berdaya secara fisik, ekonomi maupun sosial. Dampak dari pemberdayaan melalui Mawah sapi ini dapat membantu mereka untuk menjadi keluarga yang dapat dikategorikan sebagai keluarga yang sejahtera. Keuntungan yang didapat dari tradisi Mawah ini mereka gunakan untuk kebutuhan hidup mereka sehari-hari, membiayai pendidikan anak, membeli kendaraan, serta kebutuhan akan tempat tinggal.

Potensi-potensi yang dimiliki oleh masyarakat dikendalikan dan diarahkan untuk memberikan manfaat secara ekonomi bagi mereka. Upaya yang dilakukan untuk mengoptimalkan potensi tersebut yakni dengan jalan, pemerintah Kabupaten Sijunjung membuka peluang besar dalam pengembangan sektor kepariwisataan di Sijunjung salah satunya ialah adanya Geopark Silokek. Sehingga keberhasilan upaya pemberdayaan masyarakat Nagari Sijunjung melalui pemanfaatan Rumah Gadang sebagai tempat penginapan dapat mencapai keberhasilan yang maksimal yakni kesejahteraan dan kemandirian masyarakat.

Prinsip pemberdayaan menurut Dahama dan Bahtanar dalam Totok (2015: 106-108) yakni pemberdayaan dilakukan berdasarkan keragaman budaya serta kerjasama dan partisispasi. Kegiatan pemanfaatan Rumah Gadang sebagai tempat penginapan merupakan perencanaan kegiatan yang telah disesuaikan dengan memperhatikan budaya lokal yakni Perkampungan Adat. Sehingga dalam proses pemberdayaan masyarakat melibatkan partisipasi dan kerjasama antara stakeholder yang ada di Nagari Sijunjung sehingga dapat menjalankan kegiatan pemberdayaan tersebut.

Peran pemerintah sangat sentral dalam keberlansungan pemberdayaan masyarakat di Nagari Sijunjung. Keberdayaan masyarakat di Nagari Sijunjung ditumbuhkan oleh pemerintah dengan melihat potensi yang dimiliki oleh Nagari Sijunjung. Dalam pemberdayaan ini pemerintah berperan sebagai aktor pemberdayaan yang menggerakan masyarakat Nagari Sijunjung mulai dari tahap menganalisis potensi, perencanaan sampai kepada pelaksanaan kegiatan pemberdayaan. Hal ini sesuai dengan hasil pendapat Karjuni Dt. Maani tentang "Teori ACTORS dalam Pemberdayaan Masyarakat" mengatakan bahwa di Negara-negara berkembang peran pemerintah sangatlah penting dalam pemberdayaan masyarakat karena pemerintah berperan sebagai:

1. Menggali, menggerakkan, dan mengombinasikan faktor sumber daya yang tersedia seperti tenaga kerja, biaya, peralatan, partisipasi dan kewenangan yang sah.

2. Pemerintah berperan memberi bimbingan dan bantuan teknis kepada masyarakat dengan maksud agar pada suatu saat masyarakat mampu melakukannya sendiri, misalnya dalam hal perencanaan. 
3. Pemerintah dapat juga melakukan pembinaan terhadap organisasi masyarakat yang dapat berfungsi memudahkan komunikasi antara pemerintah dengan masyarakat dan melakukan hal-hal lain guna meningkatkan keberhasilan pembangunan.

Rumah Gadang sebagai tempat penginapan bagi wisatawan merupakan fasilitas utama dalam pemberdayaan masyarakat Nagari Sijunjung. Nilai seni dan sejarah yang melekat pada Rumah Gadang menjadi daya tarik bagi wisatawan yang berkunjung dan menginap di perkampungan adat. Karena Rumah Gadang masih terjaga kelestariannya dan keasliannya sehingga menawarkan pengalaman-pengalaman yang bernilai unsur kebudayaan bagi wisatawan. Salain itu suasana kehidupan masyarakat yang ada di Perkampungan Adat mencerminkan kehidupan yang sederhana dan merupakan manifestasi kehidupan masyarakat Minangkabau masa lampau. Kondisi tersebutlah yang menjadi daya tarik bagi wisatawan yang berkunjung dan ingin menginap di Rumah Gadang.

Hal ini sejalan dengan hasil penelitian Dewa Gde Satrya dan kawan-kawan tentang "Pemberdayaan Masyarakat Untuk Menciptakan Desa Ekowisata di Wonosalam, Kabupaten Jombang" yang mengatakan bahwa pergeseran konsep kepariwisataan dunia ke model ekowisata terjadi karena terjadi kejenuhan wisatawan untuk mengunjungi obyek wisatawan buatan. Oleh karena itu peluang ini selayaknya dapat dimanfaatkan secara optimal untuk menarik wisatawan untuk mengunjungi objek wisata yang berbasis alam dan budaya penduduk lokal. Tujuan menciptakan desa ekowisata tersebut dilaksanakan agar segenap komponen masyarakat, mulai dari kaum muda, sesepuh, kelompok ibu dan kaum perempuan, tokoh daerah, serta pemerintah di tingkat desa, memiliki komitmen yang sama untuk memajukan desa melalui ekowisata. Melalui berbagai kegiatan pelatihan, penyuluhan dan pendampingan, telah terjadi peningkatan pengetahuan dan keterampilan dalam hal ekowisata dan manajemen pariwisata berbasis masyarakat, pertumbuhan kualitas hidup masyarakat, serta bertambahnya pendapatan dari kunjungan wisatawan

Pemanfaatan Rumah Gadang sebagai tempat penginapan bagi wisatawan sebagai uapaya untuk memberdayakan masyarakat memiliki beberapa kendala yakni sebagai berikut:

\section{Manajemen Pengelolaan Belum Baik}

Kendala ini terjadi karena belum maksimalnya pemberian pelatihan dan pengembangan organisasi yang diberikan oleh pemerintah. Di samping itu, masih lemahnya kemampuan dan kapasitas pengelola dalam manajemen organisasi sehingga dalam pengelolaan homestay masih belum maksimal. Hal ini mengindikasikan bahwa pemberdayaan masyarakat Nagari Sijunjung melalui pemanfaatan Rumah Gadang sebagai tempat penginapan belum mampu memandirikan masyarakat. Sehingga perlu dilakukan perbaikan pendidikan pada lingkup pembinaan kepada manusia. Sebagaimana gambaran tentang lingkup pemberdayaan masyarakat menurut Totok Mardikanto (2013: 114-117) yakni bina manusia merupakan upaya pertama dan utama yang harus diperhatikan dalam setiap upaya pemberdayaan masyarakat. Pemahaman ini merupakan tujuan pembangunan untuk perbaikan mutu hidup atau kesejahteraan manusia. Salah satu upaya bina manusia yang dimaksud ialah pengembangan kapasitas entitas/kelembagaan, yang meliputi:

a. Kejelasan visi, misi dan budaya organisasi

b. Kejelasan struktur organisasi, kompetensi, dan strategi organisasi

c. Proses organisasi dan pengelolaan organisasi

d. Pengembangan jumlah dan mutu sumberdaya

e. Interaksi antar individu di dalam organisasi

f. Interaksi dengan entitas organisasi dan pemangku kepentingan yang lain. 


\section{Fasilitas Homestay Belum Maksimal}

Tidak adanya evaluasi dan pengecekan oleh pihak pengelola maupun pemerintah terkait kualitas fasilitas yang terdapat di Rumah Gadang yang dirasakan oleh wisatawan. Karena Perkampungan Adat merupakan salah satu sektor pariwisata yang berbasis ekowisata hendaknya juga memperhatikan kelayakan kualitas layanan maupun fasilitas yang diberikan kepada wisatawan.

Hal ini sejalan dengan hasil penelitian Yulia Citra Siregar tentang "Fasilitas Pada Ekowisata Danau Naga Sakti di Kabupaten Siak Sri Indrapura Riau "yang mengatakan bahwa fasilitas utama,fasilitas pendukung dan fasilitas penunjang pada ekowisata danau Naga Sakti belum cukup memadai, hal ini dikarenakan masih ada fasilitas yang belum terpenuhi serta kurang mendapat perhatian dari pengelola dan ada fasilitas yang belum berfungsi dengan maksimal dan belum tersedianya air bersih. Padahal air bersih merupakan sesuatu yang sangat diperlukan pada suatu obyek wisata. Tentu hal ini akan berdampak pada kunjungan wisatawan ke ekowisata danau Naga Sakti. Dan fasilitas yang disediakan di ekowisata danau Naga Sakti belum mampu memenuhi kebutuhan wisatawan.

Upaya pemberdayaan masyarakat harusnya tidak terfokus pada hanya satu bidang kegiatan saja yakni pemanfaatan Rumah Gadang sebagai tempat Penginapan. Disamping itu potensi lain yang bisa dilakukan beriringan dengan potensi utama yakni ada icon lain yang bisa dikembangkan sebagai upaya pemberdayaan bagi masyarakat Nagari Sijunjung yakni kuliner khas, buah-buahan, hasil kerajinan tangan dan lain sebagainya. Potensi ini perlu dikembangkan karena wisatawan tidak hanya tertarik pada satu ikon budaya saja melainkan juga bisa mendapatkan kesan yang lain dari Sijunjung. Maka dari itu perlu ada perencanaan pembangunan untuk mengembangkan hal itu yakni dengan membangun fasilitas penunjang.

Hal ini sejalan penelitian Yulia Citra Siregar tentang "Fasilitas Pada Ekowisata Danau Naga Sakti di Kabupaten Siak Sri Indrapura Riau” yang menyarankan hal-hal sebagai berikut:

a. Diharapkan untuk pengelola obyek wisata danau Naga Sakti agar dapat memperhatikan fasilitas-fasilitas yang kurang terjaga. Apalagi untuk penyediaan air bersih yang belum tersedia.

b. Diharapkan untuk menambah atraksi permainan sehingga wisatawan dapat menghabiskan waktu lebih lama di ekowisata danau.

c. kepada pengelola agar segera dapat membuka toko souvenir atau cinderamata yang khas, sehingga nantinya wisatawan yang datang mendapat kenangan dari obyek wisata danau Naga Sakti.

\section{Penutup}

Berdasarkan hasil dan pembahasan penelitian maka penulis dapat menyimpulkan dan mengemukakan beberapa saran sebagai berikut:

1. Bagi Pemerintah Kabupaten Sijunjung terkhusus bagi Dinas Pariwisata Pemuda dan Olahraga, terus melakukan percepatan pembenahan baik fisik maupun non-fisik dan masyarakat di Perkampungan Adat. Lakukan pelatihan dan sosialisasi kepada masyarakat agar masyarakat bisa menjalankan tempat penginapan secara baik dan maksimal. Kemudian lakukan pemerataan dalam pembinaan dan pemberian bantuan terhadap seluruh Rumah Gadang yang ada di Perkampungan Adat baik yang ada di Jorong Tanah Bato maupun yang di Jorong Padang Ranah.

2. Bagi pemerintah Nagari Sijunjung lakukan pembinaan dan pengawasan di Perkampungan Adat agar kegiatan pemberdayaan tersebut dapat berjalan maksimal dan tidak terjadi penyimpangan. Segera bangun kios pusat oleh-oleh agar wisatawan dapat mengetahui dan 
membeli produk-produk khas Nagari Sijunjung baik makanan, souvenir, buah-buhan dan lain sebagainya.

3. Bagi pengelola tempat penginapan/homestay agar membuat SOP dalam pengelolaan tempat penginapan sehingga informasi dan data tersaji dengan baik dan lengkap.

4. Bagi Pemangku Kepentingan di Nagari Sijunjung (KAN, Pemuda, Tokoh masyarakat, dan lain-lain) tetap lestarikan adat dan budaya yang ada di Perkampungan Adat. Usahakan di Perkampungan Adat ditanamkan bagaimana kehidupan masyarkat adat Minangkabau sesungguhnya sehingga perkampungan adat menjadi cerminan kehidupan orang Minangkabau. Oleh karena itu maka semakin banyak wisatawan yang ingin berkunjung ke Perkampungan Adat.

5. Bagi masyarakat diharapkan selalu bangun kondisi yang aman dan kondusif di Perkampungan Adat, apabila kondisi Perkampungan Adat tidak aman dan nyaman bagi wisatawan yang berkunjung maka masyarakat tidak akan mendapatkan fedback dari Perkampungan Adat.

\section{Daftar Pustaka}

Ahmad, J. (2015). Metode Penelitian administrasi Publik Teori \& aplikasi. Yogyakarta: Penerbit Gava Media.

Ape. (2018). "Silokek Sijunjung Resmi Menjadi Geopark Nasional." Media Cerdas.Web.Id. (30 November 2)

Furqan, Elva Hidayan. (2018). "Pemberdayaan Masyarakat Melalui Tradisi Mawah (Studi Kasus Pemeliharaan Ternak Sapi di Desa Mibo Kecamatan Banda Raya Banda Aceh)." Al Idarah. 2(1): 25-27

Cholisin. (2011). "Pemberdayaan Masyarakat." staff.uny.ac.id, diakses 21 Januari 2019.

Gede Satria Dewa. et al .2019. "Pemberdayaan Masyarakat Untuk Menciptakan Desa Ekowisata di Wonosalam, Kabupaten Jombang." Jurnal Pengabdian Pada Masyarakat 3(2): 179-184.

Intan, M. T. (2018). Penerapan Prinsip Ekowisata di Kawasan Ekowisata Gunung Api Purba Nglanggeran.

Janianton, D. (2006). Perencanaan Ekowisata; dari Teori ke Aplikasi. Yogyakarta: CV. Andi Offset.

Joko Sutarto. et al. (2018). Model Pemberdayaan Masyarakat Melalui Pelatihan Kecakapan Hidup Berbasis Keunggulan Lokal Desa Wisata Mandiri Wanurejo Borobudur Magelang". Jurnal Penelitian Pendidikan, 35(1): 27-40

Karjuni, Dt. Maani. (2011). "Teori ACTORS dalam Pemberdayaan Masyarakat." Demokrasi 10(1): 55-63.

Pristiwasa, I. W. (2017). "Pengembangan Kampung Adat Saribu Rumah Gadang Solok Selatan Sebagai Daerah Tujuan Wisata. Pesona , 2(2): 1-12.

Sujarwani Riau . et al . (2018). "Pemberdayaan Masyarakat Komunitas Adat Terpencil (KAT)

Oleh Pemerintah Kabupaten Lingga, Kepulauan Riau." Jurnal Antropologi: Isu-Isu Sosial Budaya , 20(1): 17-31.

Sugiyono. (2012). Metode Penelitian Kuantitatif, Kualitatif, dan R\&D. Bandung: CV.Alfabeta

Suyono, H. (2013). Pemberdayaan Maasyarakat di Era Global. Bandung: CV. Alfabeta.

Totok Mardikanto dan Poerwoko. (2015). Pemberdayaan Masyarakat dalam Perspektif Kebijakan Publik. Bandung: Alfabeta. 